\title{
ECOTHEOLOGY DAN ECOPEDAGOGY: UPAYA MITIGASI TERHADAP EKSPLOITASI ALAM SEMESTA
}

\author{
Nurasyah Dewi Napitupulu ${ }^{1,2}$, Achmad Munandar $^{3}$, Sri Redjeki $^{3}$, Bayong Tjasyono ${ }^{3}$ \\ ${ }^{1}$ STT Bala Keselamatan, Jln. Towua No. 80, Palu 94000 \\ ${ }^{2}$ Universitas Tadulako, Jln. Soekarno Hatta no. 9 Tondo, Palu 94118 \\ ${ }^{1,3}$ Pascasarjana Universitas Pendidikan Indonesia, Jln. Setiabudi no.229 Bandung 40154 \\ E-mail: nurdewi66@yahoo.com
}

\begin{abstract}
Abstrak
Eksploitasi lingkungan hidup merupakan bentuk kekerasan terhadap alam semesta yang berkontribusi pada fenomena ekologis yang terjadi dewasa ini secara lokal dan global. Kerusakan lingkungan yang terjadi merupakan isu "sekuler" dan isu "religius" atau "teologis" terintegrasi yang memerlukan perspektif ecotheology dan ecopedagogy dalam mitigasinya. Tujuan penelitian ini adalah untuk menggambarkan sikap etis-teologis mahasiwa terhadap berbagai fenomena ekologis seperti pemanasan global, deforestasi, dan penggunaan sumber-sumber energi yang dieksplorasi melalui angket sebagai instrumen penelitian. Dengan sampel berjumlah 60 orang mahasiswa dengan latar belakang agama yang berbeda, hasil penelitian menunjukkan bahwa persentase rata-rata sikap mahasiswa adalah $61,2 \%$ dengan kategori kurang. Tidak ada perbedaan yang signifikan rata-rata sikap mahasiswa terhadap fenomena lingkungan berdasarkan agama. Disimpulkan bahwa latar belakang agama tidak berkontribusi membentuk sikap mahasiswa terhadap fenomena ekologis. Untuk meningkatkan dan memperbaharui sikap mahasiwa terhadap fenomena lingkungan perlu dipertimbangkan integrasi ecotheology dan ecopedagogy untuk mengkonstruksi pemahaman konsep mahasiswa terhadap fenomena ekologi.
\end{abstract}

Kata kunci: ecotheology, ecopedagogy, fenomena ekologis, eksploitasi, sikap etis-teologis

\section{Pendahuluan}

Dalam kisah penciptaan di Alkitab, kekerasan dipahami sebagai sesuatu yang tidak boleh dan tidak mungkin dalam kerangka penciptaan Allah. Hubungan manusia dengan alam semesta atau seluruh ciptaan lahir dari karya Allah dengan Firman-Nya, disertai dengan perintah-Nya dalam Kejadian 1: 28 untuk "menaklukkan" bumi dan "berkuasa" atas semua makhluk hidup. Tidak ada klaim yang pasti apakah kerusakan bumi dan alam sekitarnya, serta kerusakan hubungan antarmanusia merupakan dampak penafsiran dari konsep "menaklukkan" dan "berkuasa" ini walaupun David Kinsley melihat ada permasalahan pokok dalam hubungan teologi Kristen dengan lingkungan hidup dimana Alkitab dan teologi Kristen berdampak negatif terhadap perkembangan spiritualitas lingkungan (Tucker, 2007). Namun demikian, 
tidak dapat dipungkiri bahwa suatu realitas dimana manusia memanfaatkan dan mengeksploitasi alam untuk memenuhi kebutuhan hidup dan juga mengeksploitasi sesama manusia untuk memenuhi hasrat diri manusia, sehingga berbagai kekerasan telah dan krisis akan terus terjadi. Menanggapi pandangan Rene Girard yang berpikir antropologis yang menekankan bahwa salib Kristus merupakan wahyu kekerasan manusia, Lucien Vanliers (2010) menyimpulkan bahwa kekerasan manusia dihidupkan jika ada krisis dalam masyarakat. Namun pada akhirnya, kekerasan itu mendamaikan masyarakat sampai krisis baru muncul. Dengan kata lain, kekerasan dan krisis terus berkelanjutan.

Berbagai masalah lingkungan telah mencapai posisi penting hingga abad ke-21 ini, dan diperkirakan akan terus meningkat. Pemanasan global, efek rumah kaca, penipisan lapisan ozon, degradasi lingkungan, polusi nuklir, pengurangan area hijau, kepunahan beberapa spesies tumbuhan dan hewan merupakan fenomena ekologis yang paling penting sekarang ini (Bonnett, 2007). Semakin banyak masalah terbuka semakin banyaknya pertanyaan tanpa jawaban. Pertanyaan-pertanyaan sekitar fenomena ekologis ini sebenarnya terkait dengan pendidikan lingkungan (ecopedagogy), sehingga pada tahun 1989, UNESCO telah mempromosikan literasi lingkungan sebagai tujuan dasar dari mitigasi dan konservasi lingkungan dari maraknya eksploitasi lingkungan hidup. Literasi lingkungan termasuk konten, keterampilan, dan proses dapat dilakukan pada masyarakat umumnya dan juga pada siswa dan mahasiswa. Berdasarkan konten, ecopedagogy memiliki fitur multidisiplin sehingga konten fenomena ekologis dapat diajarkan pada mata pelajaran umum dan mata pelajaran sains, seperti Fisika, Biologi, Kimia, dan Geogafi pada siswa SMP di Republic of Serbia (Maravic, dkk., 2014). Hasil penelitian lainnya menunjukkan bahwa mahasiswa yang mempelajari ekologi pun memiliki sikap negatif terhadap fenomena ekologis (Napitupulu, dkk, 2018; Napitupulu, dkk, 2017) dan berdasarkan kategori menerima (receiving) saja. berdasarkan kategori sikap menurut Bloom (Anderson, Krathwohl, et.al, 2001). Kategori sikap ini belum mencapai kategori pembentukan karakter (Characterization) sebagai kategori sikap tertinggi. Untuk itu, Nurasyah (2017) mengusulkan pendidikan interdisipliner dalam upaya pencapaian sikap yang menjadi karakter terhadap lingkungan.

Ecopedagogy bertujuan untuk membantu masyarakat membangun sikap ekologis melalui mitigasi lingkungan (Uzin \& Keles, 2012) sehingga pendidikan harus diarahkan pada pembentukan sikap dan perilaku terhadap pembangunan masyarakat berkelanjutan. Pendidikan yang dimaksud mencakup pendidikan agama dimana nilai-nilai religius dan spritual tentang alam semesta sebagai lingkungan hidup diajarkan secara terus-menerus dan berkesinambungan. Namun demikian, pendidikan lingkungan yang lebih dititikberatkan dalam 
perspektif sain tidak mencapai kompetensinya dalam pengembangan kepribadian dan kararter sehingga adanya jarak yang diakibatkan perbedaan interpretasi secara saintifik dan teologis harus dijembatani (Ituma, 2013). Penelitian-penelitian terdahulu menemukan kurangnya kesadaran terhadap lingkungan, baik oleh masyarakat secara umum maupun kesadaran pada level siswa. Penelitian Maravic, dkk (2014) terhadap 198 siswa SD dan SMP di Republic of Serbia menunjukkan tidak ada perbedaan yang signifikan level kesadaran ekologis antara siswa SD dengan siswa SMP. Namun, siswa SMP memiliki pengetahuan ekologis dan tingkat kesadaran yang lebih baik dibandingkan siswa SD. Hal ini disebabkan adanya faktor yang berkontribusi, seperti kurikulum pengajaran yang terintegrasi, minat terhadap isu-isu lingkungan, tindakan sosial yang sering dilakukan, dan adanya program pendidikan lingkungan di sektor swasta. Selain itu, konten lingkungan dipelajari pada mata pelajaran Biologi, Fisika, Kimia, dan Geografi.

Ituma (2013) mengutip pemahaman Unitingearthweb terhadap Ecotheology sebagai " $a$ form of constructive theology that focuses on the interrelationships of religion and nature, particularly in the light of environmental concerns." Pada umumnya, ecotheology dimulai dari premis bahwa sebuah hubungan terjadi antara pandangan manusia religius/spiritual dan degradasi alam. Dalam pemahaman ini, ada gaps yang terjadi antara perspektif saintifik dengan perspektif teologis yang dijembatani melalui fenomena ekologis. Dengan kata lain, titik temu sains dengan agama-agama ada pada ecotheology. Pemahaman Ituma ini menjadi kerangka teori dalam penelitian ini.

Selain apa yang ditemukan Itama, belum ditemukan hasil penelitian pentingnya integrasi ecopedagogy dan ecotheology. Manusia sebagai ciptaan hidup di dalam alam semesta dan memiliki keyakinan kepada Tuhan Semesta Alam. Dalam ranah spiritualitas, manusia hidup bersama dengan nilai-nilai agama yang diyakininya. Paling tidak, sikap manusia dibentuk oleh konsep teologi yang diyakini sebagai nilai dalam hidup harmoni dengan alam semesta dan ciptaan lainnya. Apakah ecotheology yang terintegrasi dengan ecopedagogy bisa menjadi dasar untuk meningkatkan kesadaran ekologis masyarakat yang dapat meminimalkan eksploitasi terhadap alam semesta dan memiliki kecerdasan dalam mitigasi fenomena ekologis, menjadi fokus pada penelitian ini. 


\section{Metode Penelitian}

Populasi dan Sampel

Populasi penelitian ini adalah mahasiswa Perguruan Tinggi di Palu, Sulawesi Tengah, yang terdiri atas Perguruan Tinggi Umum dan Perguruan Tinggi Teologi. Perguruan Tinggi Teologi terdiri atas Sekolah Tinggi Teologi Kristen, dan Sekolah Tinggi Agama Hindu. Sampel berjumlah 60 orang diambil secara purposive sampling, masing-masing 20 orang berdasarkan agamanya (Islam, Kristen, Hindu) dari masing-masing Perguruan Tinggi. Sampel juga berasal dari latar belakang daerah asal dengan lingkungan yang berbeda, yaitu lingkungan hutan, lingkungan laut, dan perkotaan.

\section{Instrumen}

Instrumen sebagai alat pengumpul data yang digunakan dalam penelitian ini merupakan instrumen nontes berupa angket untuk sikap ekologis tipe skala Likert dengan enam pilihan jawaban (skor 1-6) untuk alternatif jawaban selalu mengalami (SL), sering mengalami (SR), kadang-kadang mengalami (KD), kadang-kadang tidak mengalami (KT), sering tidak mengalami (SRT), dan selalu tidak mengalami (SLT). Instrumen penelitian telah divalidasi ahli dan divalidasi secara statistik menggunakan program SPSS Version 19.0 for Windows. Hasil uji reliabilitas diperoleh 0,876 dengan kriteria sangat tinggi. Angket sikap ekologis terdiri atas 60 pertanyaan yang disebar berdasarkan fenomena ekologis perubahan iklim, deforestasi, penggunaan sumber-sumber energi sebagaimana terdapat pada Tabel 1.

Tabel 1 Kisi-kisi Instrumentasi Sikap Ekologis

\begin{tabular}{|c|c|c|c|c|}
\hline \multirow[t]{2}{*}{$\begin{array}{l}\text { Karakteristik } \\
\text { Sikap }\end{array}$} & \multirow[t]{2}{*}{ Indikator } & \multicolumn{3}{|c|}{$\begin{array}{l}\text { Jumlah Pernyataan Sikap/ } \\
\text { Fenomena ekologis }\end{array}$} \\
\hline & & $\begin{array}{l}\text { Perubahan } \\
\text { Iklim }\end{array}$ & Deforestasi & $\begin{array}{l}\text { Penggunaan } \\
\text { Energi }\end{array}$ \\
\hline Valuing & $\begin{array}{l}\text { Melibatkan penentuan nilai, } \\
\text { keyakinan atau sikap dan } \\
\text { komitmen }\end{array}$ & 9 & 12 & 9 \\
\hline Characterisation & $\begin{array}{l}\text { Memiliki karakter yang } \\
\text { peduli terhadap lingkungan }\end{array}$ & 9 & 12 & 9 \\
\hline Jumlah Pertanyaa & & 18 & 24 & 18 \\
\hline
\end{tabular}

Teknik Analisis Data

Berdasarkan jenis data yang diperoleh pada penelitian ini merupakan data kualitatif dan kuantitatif maka analisis data dilakukan menggunakan metoda mix method. Analisis data 
kualitatif dilakukan dengan metode analisis kritis terhadap konsep-konsep ecopedagogy dan ecotheology dan berbagai fenomena ekologis yang ditemukan dari berbagai literatur dan hasilhasil penelitian terbaru dari berbagai jurnal. Analisis data kuantitatif berupa sikap ekologis mahasiswa berdasarkan agama dan jenis kelamin dideskripsikan berdasarkan persentase. Kategorisasi sikap ekologis menggunakan kriteria yang diadopsi dari Mardapi (2011), disajikan pada Tabel 2.

Tabel 2 Kategorisasi Penguasaan Kompetensi

\begin{tabular}{cc}
\hline Tingkat Penguasaan (TP) & Kategori \\
\hline $90 \%-100 \%$ & Baik Sekali \\
$80 \%-89 \%$ & Baik \\
$70 \%-79 \%$ & Cukup \\
$<70 \%$ & Kurang \\
\hline
\end{tabular}

\section{Hasil dan Pembahasan Penelitian}

Hasil Penelitian

Hasil jawaban angket yang menggambarkan sikap ekologis mahasiswa berdasarkan latar belakang agama dipaparkan pada Tabel 3. Data menunjukkan bahwa rata-rata sikap ekologis berlatar belakang agama Hindu adalah 62,3\%, agama Islam adalah 61,5\%, dan agama Kristen adalah 59,8\%. Sikap ekologis terhadap fenomena ekologis perubahan iklim, deforestasi, dan penggunaan energi masing-masing adalah 61,6\%, 62,9\%, dan 59,0\%. Berdasarkan kategori penguasaan kompetensi pada Tabel 2 menunjukkan bahwa sikap ekologis mahasiswa berdasarkan latar belakang agama adalah 61,2\% dengan kategori kurang baik. Demikian juga sikap ekologis berdasarkan ketiga fenomena ekologis berada pada kategori kurang baik.

Tabel 3 Persentase Sikap Ekologis Berdasarkan Agama

\begin{tabular}{lcccc}
\hline & \multicolumn{3}{c}{ Fenomena Ekologis } \\
\cline { 2 - 5 } Agama & $\begin{array}{c}\text { Perubahan } \\
\text { Iklim }\end{array}$ & Deforestasi & $\begin{array}{c}\text { Penggunaan } \\
\text { Energi }\end{array}$ & $\begin{array}{c}\text { Rata-rata } \\
(\%)\end{array}$ \\
\hline Hindu & 63,0 & 65,7 & 58,3 & 62,3 \\
Islam & 62,8 & 62,0 & 59,5 & 61,5 \\
Kristen & 59,1 & 60,9 & 59,3 & 59,8 \\
\hline Rata-rata & 61,6 & 62,9 & 59,0 & 61,2 \\
$(\%)$ & & & &
\end{tabular}


Gambar 1 menunjukkan bahwa sampel beragama Hindu memiliki sikap ekologis tertinggi pada fenomena deforestasi; sampel beragama Islam tertinggi pada fenomena perubahan iklim; dan sampel beragama Islam sikap tertinggi pada fenomena deforestasi. Dari ketiga fenomena ekologis, ketiga sampel memiliki sikap terendah pada fenomena penggunaan energi.

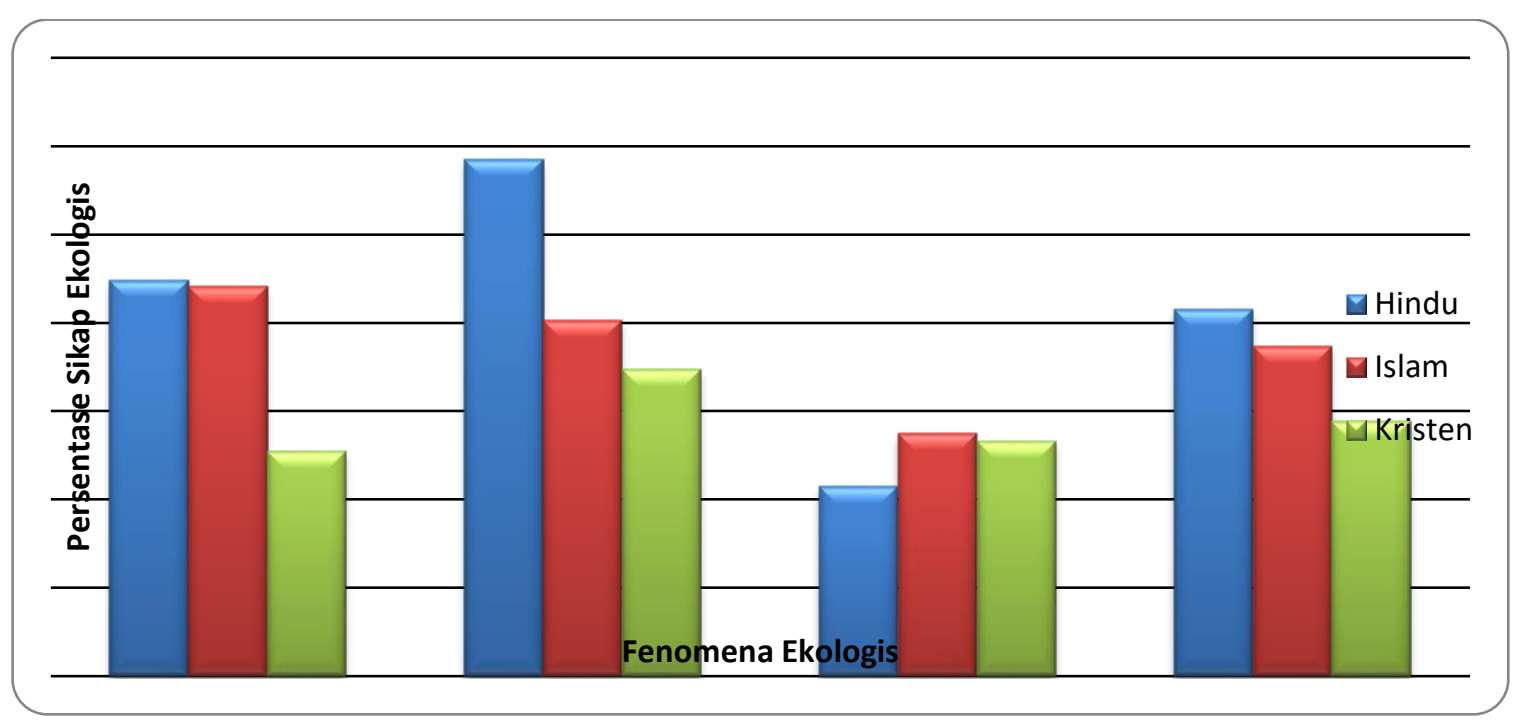

Gambar 1 Grafik Persentase Sikap Ekologis Berdasarkan Agama

Hasil penelitian sikap ekologis mahasiswa berdasarkan latar belakang gender atau jenis kelamin ditunjukkan pada Gambar 2.

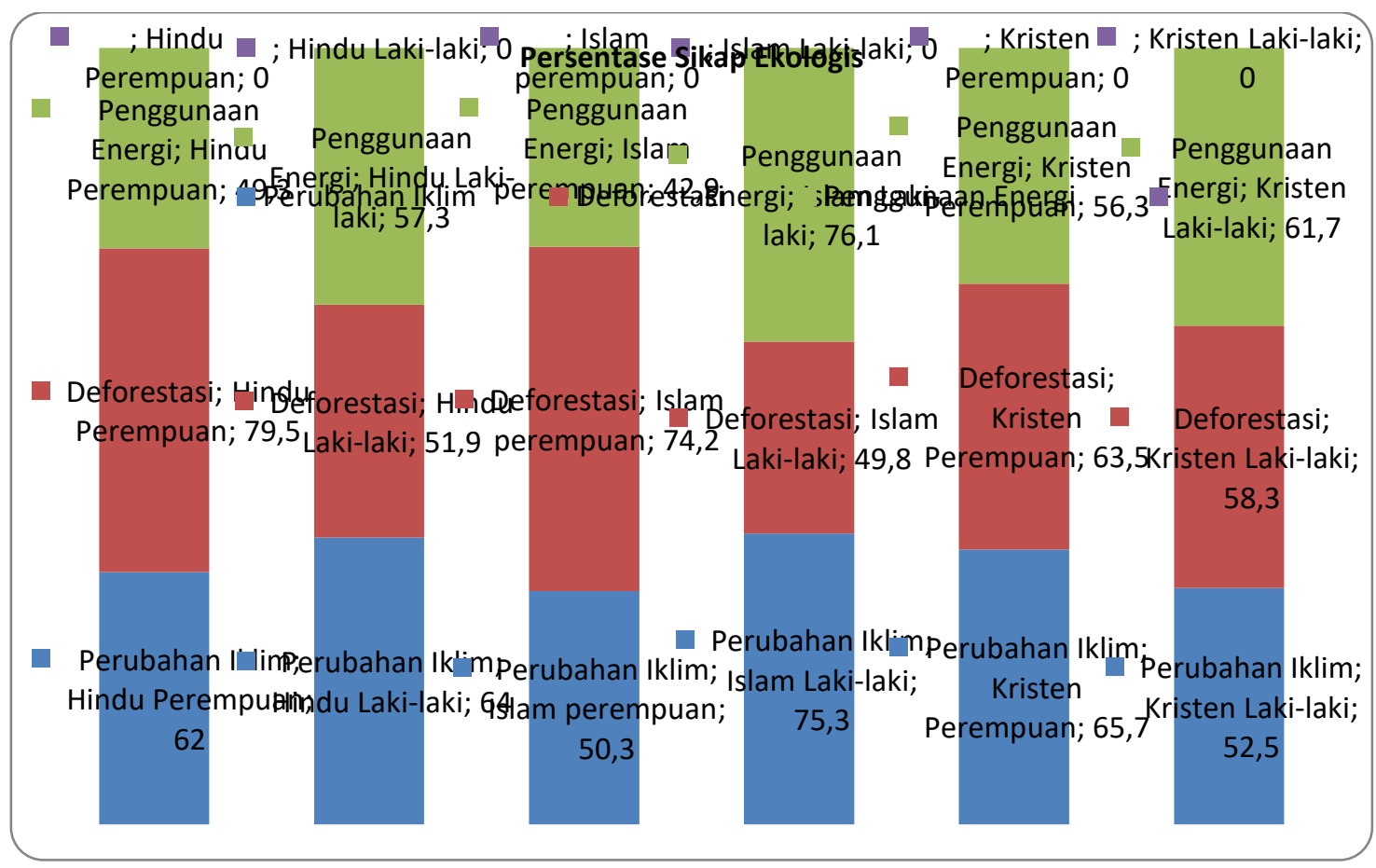

Gambar 2 Grafik Persentase Sikap Ekologis Berdasarkan Agama dan Jenis Kelamin 
Sikap ekologis berdasarkan jenis kelamin menunjukkan bahwa persentase sikap perempuan lebih tinggi dari laki-laki pada ketiga fenomena ekologis, baik yang beragama Hindu, Islam, maupun Kristen. Sebaliknya, sikap ekologis laki-laki lebih tinggi dari perempuan adalah terhadap fenomena penggunaan energi, pada semua agama. Namun demikian, sikap ini tertinggi pada sampel beragama Islam $(76,1 \%)$. Sikap ekologis laki-laki pada fenomena perubahan iklim lebih tinggi dari perempuan tetapi pada sampel beragama Hindu dan Islam.

\section{Pembahasan}

Agama dan Kesadaran Lingkungan

Agama berperan dalam proses pembentukan sistem nilai dalam diri seseorang sehingga setiap orang pemeluk agama mampu menggunakannya dalam memahami, mengevaluasi, dan menafsirkan situasi dan pengalaman. Dengan kata lain, sistem nilai yang dimilikinya terwujud dalam bentuk norma-norma yang menunjuk kepada sikap diri. Dalam praktiknya, Kaswardi (1993) menyebutkan bahwa nilai memberikan pola kehidupan dalam bertingkah laku, berpikir, dan bersikap. Agama membentuk dan mengembangkan kesadaran akan diri sendiri, sesama manusia, dan alam semesta sebagai lingkungan hidup. Agama yang tidak menyentuh ranah kehidupan secara menyeluruh akan mengakibatkan tumpulnya kesadaran terhadap alam semesta dan segala isinya. Dampaknya adalah terjadi berbagai tindak kekerasan terhadap diri sendiri, terhadap sesama manusia, dan terhadap alam semesta dan segala isinya, atas nama agama, baik dengan sadar atau tidak sadar karena kesalahan memahami atau menafsirkan ajaran agama. Temuan penelitian yang dipaparkan pada Tabel 3 dan Gambar 1 menunjukkan bahwa sikap ekologis berdasarkan latar belakang agama berada kategori kurang baik. Hasil ini menggambarkan bahwa nilai-nilai ajaran agama tidak berkontribusi dalam pembentukan sikap terhadap lingkungan. Penghargaan manusia terhadap lingkungannya juga terkonsep dalam ajaran agama-agama, dimana agama berada pada eksistensi budaya. Dalam pemahaman ini agama diperlukan untuk memberikan arah kesadaran etik dalam kehidupan berbudaya. Dengan demikian konsep ecotheology menjadi dasar dalam membangun kesadaran etis terhadap ekologi. Pemahaman konsep teologi lingkungan dalam ranah penatalayanan alam semesta berpengaruh terhadap respon dan sikap etis dan spritual terhadap alam semesta berdasarkan nilai agama penganutnya.

Nilai-nilai ajaran agama Hindu mencakup nilai kosmologi yang membimbing tingkahlaku untuk melestarikan alam. Bentuk pelestarian alam yang lahir dari kesadaran akan ajaran agama Hindu adalah penghijauan hutan (Wana Kartika). Itulah sebabnya, hasil penelitian menunjukkan bahwa sampel beragama Hindu memiliki sikap ekologis tertinggi pada 
fenomena deforestasi. Dengan kata lain, nilai-nilai ajaran agama Hindu memberi kontribusi dalam pembentukan sikap ekologis masyarakat Hindu terhadap hutan. Menurut Atharma Weda XII,1.1 "kebenaran yang Maha Besar, Hukum Alam yang harus dipatuhi, pengabdian, kesederhanaan, doa dan pengorbananlah yang dapat mempertahankan bumi ini sehingga dapat terus berlangsung" (Siahaan, 2004 ). Ini menunjukkan bahwa nilai-nilai agama Hindu mencakup sikap untuk menjaga dan memelihara bumi, terutama melalui menjaga kelestarian hutan. Bahkan Amitabha (1997) dalam Siahaan (2004) mengatakan bahwa lingkungan memegang peran sangat penting terhadap tubuh manusia, sehingga lingkungan yang baik akan memberi harmoni pada getaran dalam tubuh.

Haidar (1997) mengatakan bahwa kesadaran etik dalam kehidupan berbudaya lebih bermakna dan memiliki kedalaman substantif melalui agama. Perspektif Islam mengatakan bahwa kesadaran hubungan agama dan budaya (bagian dari kearifan lingkungan) disinggung dalam Al-Qur'an. Alkitab sendiri memuat nilai-nilai religius yang dimulai dari penciptaan alam semesta dan segala isinya (Kejadian 1). Manusiapun diciptakan dan ditempatkan pada lingkungan hidup yang indah - Taman Eden - dan diberi tanggung jawab untuk mengusahakan bumi dan memelihara harmoni ciptaan dalam relasi dengan Tuhan Sang Pencipta. Relasi ini merupakan relasi spiritual antara Allah, manusia, dan alam semesta (dunia) yang melahirkan ecotheology sebagai respons gereja atas fenomena pemanasan global akibat deforestasi dan penggunaan sumber-sumber energi dan merupakan ancaman kehancuran dunia ciptaan Allah. Melalui ecotheology, prinsip-prinsip dasar teologi tentang ciptaan dan keutuhannya dapat dipahami dan direfleksikan dalam perlindungan dan perawatannya.

\section{Kesadaran Ekologis sebagai Mitigasi Eksploitasi Ciptaan}

Bentuk kekerasan terhadap alam yang terlihat sebagai kerusakan alam harus juga dipahami sebagai persoalan teologis selain sebagai persoalan saintis. Sebagai persoalan teologis, ancaman ecocida (kematian lingkungan) merupakan bagian dari Misi Penyelamatan dan bahkan Perlindungan Gereja dan Teologi (Erari, 2017). Akhir-akhir ini berkembang bentuk kekerasan berupa kekerasan terhadap diri sendiri, sesama, dan alam semesta. Kekerasan terhadap diri sendiri ditandai dengan semakin meningkatnya bunuh diri di kalangan masyarakat beragama. Kekerasan dan eksploitasi manusia dengan sesamanya terlihat dari semakin maraknya kejadian kekerasan dalam rumah tangga (KDRT), inses, pelecehan seksual terhadap anak, mempekerjakan anak di bawah umur, perdagangan manusia. Kekerasan terhadap perempuan pada tahun 2016 tercatat 259.150 kasus dalam bentuk KDRT, dan kekerasan dalam berpacaran. Dari jumlah kasus tersebut, $42 \%$ mengalami kekerasan fisik, 34\% kekerasan 
seksual, 14\% kekerasan psikis, dan selebihnya kekerasan ekonomi (Kompas, 7 Maret 2017). Demikian juga kekerasan dan eksploitasi terhadap alam semesta yang terus meningkat dalam berbagai bentuknya.

Kekerasan terhadap alam semesta terlihat dari meningkatnya eksploitasi terhadap bumi. Bumi yang dalam bahasa Sanskerta disebut prthvi atau "dewi" (bergender perempuan) dalam agama Hindu, atau "ibu pertiwi" dalam bentuk personifikasi Nasional Indonesia telah menjadi objek tindak kekerasan sepanjang catatan sejarah. Data hasil penelitian pada Gambar 2 ditemukan bahwa sikap laki-laki lebih buruk dari sikap perempuan terhadap fenomena ekologi, baik pada agama Hindu, Islam, maupun Kristen. Hasil ini menunjukkan adanya kesejajaran tingginya kekerasan terhadap perempuan (diartikan dilakukan oleh laki-laki), baik kekerasan seksual maupun kekerasan fisik. Dalam tataran praksis analogis, perburuan binatang-binatang dan hewan-hewan langka banyak dilakukan laki-laki. Apakah itu disebabkan oleh pembagian peran laki-laki di luar rumah dan perempuan melakukan kerja domestik, perlu kajian mendalam. Namun demikian, Erari (2017) menguraikan bahwa KTT Bumi (Earth Summit) pada tahun 1992 yang bertujuan membicarakan lingkungan dan pembangunan (UNCED), dihadiri 37 Dewan Gereja Sedunia (WCC), diwarnai dengan hadirnya 10.000 perempuan dari seluruh dunia yang berkomitmen untuk menjaga alam dari kerusakan karena ulah kaum laki-laki. Komitmen para perempuan ini tampak sebagai "tuduhan" terhadap kaum laki-laki sebagai perusak bumi. Jika melirik ke kata "ibu pertiwi" secara etimologis, maka seruan para perempuan ini bisa ditarik benang merahnya dengan maraknya kekerasan dan eksploitasi "ibu bumi” sebagai perempuan. Dengan demikian, penyelamatan bumi atau mitigasi terhadap kekerasan dan eksploitasi bumi dapat dilakukan dengan mengubah perspektif laki-laki terhadap perempuan dan dengan meningkatkan kesadaran ekologis dalam ranah bumi sebagai sumber damai sejahtera. Tentu hal ini masih menjadi perdebatan teologis dari perspektif teologi feminis.

Hasil wawancara terhadap mahasiswa (Kristen) menunjukkan pandangan mereka terhadap upaya mitigasi yang bisa dilakukan dalam membangun kesadaran lingkungan adalah internalisasi konsep-konsep saintifik-religius ekologi dalam setiap perkuliahan, dan sikap menghargai dan menghormati alam semesta sebagai citra Allah. Selain itu, kajian ulang terhadap penafsiran-penafsiran yang salah mengenai kekuasaan manusia. Secara praktis, bentuk mitigasi adalah penggunaan bahan-bahan yang ramah lingkungan, mengurangi penggunaan kertas yang bersumber dari pohon-pohon di hutan, menanam pohon, hemat menggunakan energi listrik. Dari ranah spiritual, mitigasi dilakukan dengan doa, dan mencintai makhluk hidup lainnya sebagai ciptaan dalam citra Allah. Hal ini senada dengan apa yang 
dikatakan Santo Fransiskus bahwa semua ciptaan yang bukan manusia sebagai saudara lakilaki dan perempuan, dimana alam semesta harus dihargai dan dihormati (Tucker, 2007; Borong, 1998).

\section{Simpulan dan Saran}

Manusia berkontribusi dalam terjadinya berbagai kekerasan terhadap ciptaan Tuhan dan merusak keutuhannya akibat eksploitasi. Eksploitasi terjadi karena sikap ekologis yang kurang baik karena nilai-nilai agama tidak membentuk karakter peduli lingkungan. Kurangnya pemahaman konsep ekologi dari perspektif saintifik juga memberi kontribusi dalam pembentukan sikap ekologis. Bahkan, pemahaman ekologi secara teologis dalam perspektif ecotheology yang dualisme dan tafsir negatif terhadap ekologi dalam Alkitab berperan dalam eksploitasi ciptaan sebagai suatu kekerasan fisik, psikis, dan spiritual. Diharapkan nilai-nilai agama memengaruhi kesadaran para pemeluknya dalam pembentukan sikap ekologis, dan membentuk karakter yang menghargai Allah Semesta Alam dan keutuhan ciptaan-Nya yang indah dan sangat indah.

\section{Daftar Rujukan}

Anderson, L. W., and. Krathwohl, D. R, et.al (Eds.). 2001. A Taxonomy for Learning, Teaching, and Assessing: A revision of Bloom's Taxonomy of Educational Objectives. Boston, MA: Allyn \& Bacon.

Bonnett, M. 2007. Environmental Education and the Issue of Nature. Journal of Curriculum Studies, 39 (6), hal. 707-721.

Borong, R. P. 1998. Etika Lingkungan Hidup dari Perspektif Teologi Kristen. Jurnal Pelita Zaman. Volume 13, Nomor 1.

Borong, R. P. 1998. Teologi dan Ekologi: Peran Pendidikan Teologi dalam Mengembangkan Teologi Ekologi. Jakarta: Sekolah Tinggi Teologi Jakarta.

Deane-Drummond, C. 2015. Teologi dan Ekologi. Jakarta: BPK Gunung Mulia.

Erari, K.P. 2017. Spirit Ekologi Integral. Jakarta: BPK Gunung Mulia.

Groome, T.H. 2017. Christian Religious Education. Jakarta: BPK Gunung Mulia.

Haidar, M. A. 1997. Islam dan Kemajemukan Budaya: Memahami Alam dalam kearifan Tradisional dan Konsep Agama bagi Pelestarian Lingkungan. Konrad Adenauer Foundation. 
Ituma, E. A. 2013. Christocentris Ecotheology and Climate Change. Open Journal of Philosophy, Vol. 3, No. 1A, (hal. 126-130).

Jackson L. L. 2013. Cultivating The Environmental Awareness Of Third Graders Through Inquiry Based Ecopedagogy: Impact On Students' Achievements And Attitudes. Dissertation, Georgia: Georgia Southern University.

Kaswardi, E.M.K, (Ed.). 1993. Pendidikan Nilai Memasuki Tahun 2000. Jakarta: Grameis Widia Sarana Indonesia.

Maravić, M., Cvjetićanin, S. \& Ivkovic, S. 2014. Level of Environmental Awareness of Students in Republic of Serbia. World Journal of Education Vol. 4, No. 3, hal. 13-18.

Napitupulu, N. D., Munandar, A., Redjeki, S., dan Tjasyono, B. 2017. Shifting Attitude From Receiving to Characterisation as An Interdisciplinary Learning Toward Ecological Phenomena. Dalam Proceeding International Seminar On Science Education, Vol. 3, (hal. 119-124). Yogyakarta: Yogyakarta State University.

Napitupulu, N. D. and Munandar, A. 2017. Describing The Impact Inquiry-Based Ecopedagogy on Preservice Physics Teachers' Achievement and Attitudes. AIP Conference Proceeding. 1848, 060004-1-060004-7; doi: 10.1063/1.4983972

Napitupulu, N. D., Munandar, A., Redjeki, A., dan Tjasyono, B. 2018. Determining Students' Attitudes Toward Ecological Phenomena in Learning Environmental Physics Subject. Advance in Social Science Education and Humanities Research, volume 174, (hal. 274277). Published by Atlantis Press.

Pazmino, R.W. 2012. Fondasi Pendidikan Kristen. Jakarta: BPK Gunung Mulia.

Putranti, B.D. \& Natar, A.N. (eds.). 2016. Perempuan, Konflik, \& Rekonsiliasi: Perspektif Teologi dan Praksis. Jakarta: BPK Gunung Mulia.

Siahaan, N.H.T. 2004. Hukum Lingkungan dan Ekologi Pembangunan. Jakarta: Erlangga.

Tucker, M. E. \& Grim, J. A. (ed.). 2007. Agama, Filsafat, \& Lingkungan. Yogyakarta: Kanisius.

Unesco. 2011. Education for Sustainable Development Country (Jakarta: Unesco Office)

Uzin, F. V., \& Keles, O. 2012. The effects of nature education project on the environmental awareness and behavior. Procedia-Social and Behavioral Sciences, 46, (hal. 29122916).

Van Liere, L. 2010. Memutus Rantai Kekerasan: Teologi dan Etika Kristen di Tengah Tantangan Globalisasi dan Terorisme. Jakarta: BPK Gunung Mulia. 